1977. Calcareous Algae. Developments in Palaeontology and Stratigraphy, 4. Elsevier, New York, $185 \mathrm{p}$.

-., N. P. JAMES, AND R. N. GINSBURg. 1974. The puzzling Paleozoic phylloid algae-Holocene answer in squamariacean calcareous red algae. American Association of Petroleum Geologists, Annual Meeting, 2:82-83.
ZHANG YUN. 1989. Multicellular thallophytes with differentiated tissues from late Proterozoic phosphate rocks of South China. Lethaia, 22:113-132.

ACCEPTED 26 JUNE 1990

Harvard University provided $\$ 500$ in support of this article.

\title{
THE FORAMINIFERAL GENERA PARAROTALIA, NEOROTALIA, AND CALCARINA: TAXONOMIC REVISION
}

\author{
LUKAS HOTTINGER, ${ }^{1}$ ELWIRA HALICZ, ${ }^{2}$ AND ZEEV REISS ${ }^{2}$ \\ 'Geologisch-Palaeontologisches Institut der Universitaet Basel, \\ Bernoullistrasse 32, CH-4056 Basel, Switzerland and \\ ${ }^{2}$ Department of Geology, Institute of Earth-Sciences, The Hebrew University of Jerusalem, \\ 91904 Giv'at Ram, Jerusalem, Israel
}

\begin{abstract}
Scanning electron microscopy of the architecture of Rotalina inermis Terquem, 1882, the type-species of the genus Pararotalia Le Calvez, 1949, and of Rotalia mexicana Nuttall, 1928, the type-species of the genus Neorotalia Bermudez, 1952, reveals that both taxa have in common: 1) an umbilical bowl closed by either a single or a compound umbilical plug; 2) an interiomarginal extraumbilical aperture, restricted by a toothplate that protrudes with a free edge into the aperture and forms an umbilical spiral canal; and 3) a septal flap and intraseptal interlocular spaces. Rotalia mexicana, however, also possesses an enveloping canal-system, similar to that found in the Calcarinidae. For this reason Neorotalia must be regarded as a valid distinct genus, not synonymous with Pararotalia, as proposed by some authors. Calcarina calcar d'Orbigny, 1839, variously placed by authors in Rotalia Lamarck, 1804, in Pararotalia Le Calvez, 1949, and lately again in Calcarina d'Orbigny, 1826, is shown to possess the same basic architecture as Neorotalia and is placed, consequently, into this latter genus. Irregular supplementary apertures occurring in $N$. calcar are not considered of generic value and neither are they regarded as indicating a relationship with Nautilus spengleri Gmelin, 1788, the type-species of Calcarina. The latter, although characterized by a complex enveloping canal-system, possesses primary multiple interioareal main apertures, surrounded by thick rims, as well as a small umbilical plate, but lacks a toothplate with a free edge. For comparison, Pararotalia spinigera (Le Calvez, 1949) and Neorotalia viennoti (Greig, 1935) were also studied. The subfamily Pararotaliinae Reiss, 1963, is emended to include the canal-system as a characteristic feature. A glossary of selected terms is appended.
\end{abstract}

\section{INTRODUCTION}

C ALCARINA CALCAR d'Orbigny, 1826, was repeatedly discussed in the literature with regard to its architecture and systematic position. It was placed in the genus Rotalia Lamarck, 1804, by Brady (1884) and by Hofker (1927), included in Pararotalia Le Calvez, 1949, by Reiss and Merling (1958), Reiss (1963), Hofker (1970), and Hansen and Reiss (1971), and lately assigned again to Calcarina d'Orbigny, 1826, by Le Calvez (1977), Hottinger and Leutenegger (1980), and Reiss and Hottinger (1984).

Differences of opinion stem from conflicting, in many cases incomplete or incorrect, descriptions of the architecture of $C$. calcar and of other species with which it has been compared or associated. Confusion has also arisen as a result of differing interpretations of certain test elements (and terminology applied to them) by various authors. Rigorously defined test elements are, however, besides their taxonomic value, of considerable importance in the understanding of functional morphology of the test and in relating test architecture to cytoplasmic differentiation (Hottinger and Dreher, 1974; Hottinger, 1978; Hottinger and Leutenegger, 1980).

Within the framework of a comprehensive study by the present authors of the foraminifera extant in the Gulf of Aqaba, Red
Sea, the architectural details of Calcarina calcar were reexamined by means of scanning electron microscopy. In order to solve the problems involved, the necessity arose to study, in addition, the following species with regard to certain morphological characters: 1) Rotalina inermis Terquem, 1882 (topotypes), the type species of Pararotalia, and 2) Pararotalia spinigera (Le Calvez, 1949), both from the Lutétien of Grignon, Paris Basin; 3) Rotalia mexicana Nuttall 1928, emend. Poag, 1966, the type-species of the genus Neorotalia Bermudez, 1952, placed generally in the synonymy of Pararotalia (see Hofker, 1957; Reiss and Merling, 1958; Reiss, 1963; Loeblich and Tappan, 1964, 1987), from the Lower Miocene of Victoria, Australia; 4) Rotalia viennoti Greig, 1935 (topotypes from the Oligocene of Ramla, Israel), placed by Bermudez (1952) in Neorotalia and by Reiss and Merling (1958) in Pararotalia; as well as 5) Nautilus spengleri Gmelin, 1788, the type species of the genus Calcarina, from Keij Island, Indonesia, and from Sybai, Philippines.

The present paper summarizes observations on certain architectural characters of the taxa mentioned above and the resulting systematic conclusions. However, no complete redescription at species level is included.

Terminology of foraminiferal test elements is far from being 
unified and for this reason a glossary of some important terms, as used or redefined lately by the present authors, is appended at the end of this article.

\section{SYSTEMATIC PALEONTOLOGY \\ Suborder Rotalina \\ Delage and Hérouard, 1896 \\ Superfamily ROTALIACEA \\ Ehrenberg, 1839 \\ Family Rotalidae Ehrenberg, 1839 \\ Subfamily PARAROTALIINAE \\ Reiss, 1963, emend. herein}

Diagnosis. - Trochospiral test with single interiomarginal main aperture into which a toothplate protrudes with a free edge; irregular supplementary apertures may be present; canal-system composed of intraseptal interlocular spaces, of a spiral umbilical canal formed by interconnected toothplates, and, in some genera, of enveloping canals produced by secondary lamination.

Genus Pararotalia Le Calvez, 1949

PARAROTALIA INERMIS (Terquem, 1882)

Figure 1.1, 1.3, 1.4

Rotalina inermis TERQUEM, 1882, p. 68, Pl. 6, fig. 1.

Pararotalia inermis (Terquem). Le CALVEz, 1949, p. 32, Pl. 3, figs. 54 56; LOEBLICH AND TAPPAN, 1957 (emend.), p. 14-15, P1. 1, figs. 2, 3, text-figs. 4, 5; ReIss AND Mering, 1958, p. 1-17, PI. 2, figs. 4-12, Pl. 5, figs. 16-18; LoEBLICH AND TAPPAN, 1964, p. C612-C613, Pl. 486, figs. 1-3; Le CAlvez,, 1970, p. 163, Pl. 34, figs. 6, 7; HANSEN AND Reiss, 1971, p. 335, Pl. 9, fig. 6, Pl. 10, fig. 3; LOEBLICH AND TAPPAN, 1987, p. 659, Pl. 755, figs. 18-21.

Review. - Le Calvez (1949) described deeply incised sutures on the ventral side, a single umbilical plug, and an interioareal, elliptical aperture surrounded by a lip. Loeblich and Tappan (1957) described deeply depressed sutures on the ventral side, prominent umbilical shoulders, and the aperture as originally interiomarginal and extraumbilical-umbilical with a lip, modified, before the development of the next chamber, by a delicate umbilical plate into an areal ovate or comma-shaped opening, an internal septum being formed at the junction of umbilical plate and chamber wall. Reiss and Merling (1958) regarded the "umbilical plate" reported by Loeblich and Tappan (1957) an actual chamber wall and the "internal septum" as a primary toothplate. Reiss and Merling used, however, the term "toothplate" in a broad sense (Hofker, 1951), hence including foramenal plate, umbilical plate, and cover plate (see Müller-Merz, 1980, and appended Glossary); they compared the toothplate of Pararotalia to the plate of Cuvillierina, Debourle, 1955, proven by Müller-Merz (1980) to be a typical umbilical plate (see Glossary). The aperture was described and figured by Reiss and Merling (1958) as interiomarginal, extraumbilical and the intercameral foramen as areal, modified by the attachment (in adaxial position) of the toothplate. The presence of a septal flap was demonstrated and the deeply incised ventral sutures were shown by Reiss and Merling (1958) to correspond to intraseptal interlocular spaces ("intraseptal passages"), now regarded as part of the canal-system (Hottinger, 1978). Hansen and Reiss (1971), in disagreement with Reiss and Merling (1958), described in all Pararotalia a slightly contorted "foramenal plate," protruding into the chamber, to which an "umbilical cover plate" is attached in each preceding chamber, similar to the situation in Ammonia Brünnich, 1772. Lately, Loeblich and Tappan (1987), in their new description of the genus Pararotalia, reported the presence of a septal flap doubling the septa and described the aperture as interiomarginal, extending obliquely into the apertural face, and the intercameral foramen as areal, due to the attachment of an imperforate toothplate that extends to the distal margin of the aperture.

Observations and remarks. - The accompanying Figures 1.1, $1.3,1.4$, shows the slightly inflated ventral (umbilical) chamber walls, which are smooth, except near the peripheral carina where they are finely pustulate, the prominent umbilical shoulder, the septal flap, and the deep and open intraseptal interlocular spaces on the ventral side communicating with a deep furrow between inner ventral walls, producing the umbilical bowl, and the single umbilical plug. In dissected chambers (Figure 1.3, 1.4), the areal intercameral foramen with a thick lip or rim and the toothplate are shown. Originating from the septal flap and connected to the inner ventral chamber wall, an imperforate toothplate extends to the distal chamber wall, attached to the dorsal corner of the primarily interiomarginal, extraumbilical aperture, and protruding with a free, serrated edge into the latter. It is folded both parallel and normal to the axis of coiling and produces with the adjacent preceding coil a space. As shown by Reiss and Merling (1958, Pl. 2, figs. 5, 9) and by Hansen and Reiss (1971, Pl. 10, fig. 2; see also Pararotalia sp. on Pl. 10, fig. 1), each toothplate is attached to the preceding one in adaxial position. This produces a narrow continuous spiral space, here regarded as a canal. It communicates behind the fold of the toothplate with the main chamber lumen, as well as with the furrow around the umbilical plug. These findings are in general agreement with Reiss and Merling (1958) and with Loeblich and Tappan (1987), but differ from the descriptions by Loeblich and Tappan (1957, 1964) and by Hansen and Reiss (1971).

The presence in Pararotalia of a toothplate (s. str.) with a free edge, and the absence of such features as an umbilical plate (like e.g., in Rotalia or in Cuvillierina), of a foramenal plate connected to a cover plate (like e.g., in Ammonia), or of folia with foliar apertures (in the sense of Levy et al., 1980, like in Rotalia or in Ammonia) (see Glossary) set the Pararotaliinae well apart from the Rotaliinae Ehrenberg, 1839, Cuvillierininae Loeblich and Tappan, 1964, and Ammoniinae Saidova, 1981, in the classification of Loeblich and Tappan (1987). The description of the Pararotaliinae is emended here to include the canal-system (compare, however, Loeblich and Tappan, 1987).

\section{PARAROTALIA SPINIGERA}

(Le Calvez, 1949)

Figure 1.2, 1.5-1.8

Globorotalia spinigera (Terquem). Le CALVEZ, 1949, p. 39, P1. 6, figs. 97-98; Le CALVEZ, 1952, p. 48.

Pararotalia spinigera (Le Calvez). LoEBLICH AND TAPPAN, 1957 (emend.), p. 18, Pl. 4, figs. 1-3; Le Calvez, 1970, p. 161, Pl. 39, fig. 6.

Review. - Loeblich and Tappan (1957) described the chambers as gently convex on the ventral side with a pronounced umbilical shoulder and deeply depressed intercameral sutures, a single umbilical plug, and the short blunt, peripheral spines arising from each chamber. The aperture is described as interiomarginal and extraumbilical-umbilical with a lip, restricted to an areal, comma-shaped opening by a secondary umbilical plate which forms also a protruding "lower lip" roughly parallel with the lower margin of the chamber. Le Calvez (1970) regarded this species as a kind of Rotalia with an internal toothplate. This agrees with the latest redescription of the genus Pararotalia by Loeblich and Tappan (1987).

Observations and remarks. - Figure 1.2, 1.8, shows the slightly inflated chambers on the ventral side and the deeply depressed sutures forming the intraseptal interlocular spaces, a deep furrow between the umbilical bowl and the single umbilical plug, the pustules, sometimes aligned or forming riblets, on the ventralperipheral margin and on the carina, as well as (see also Figure 

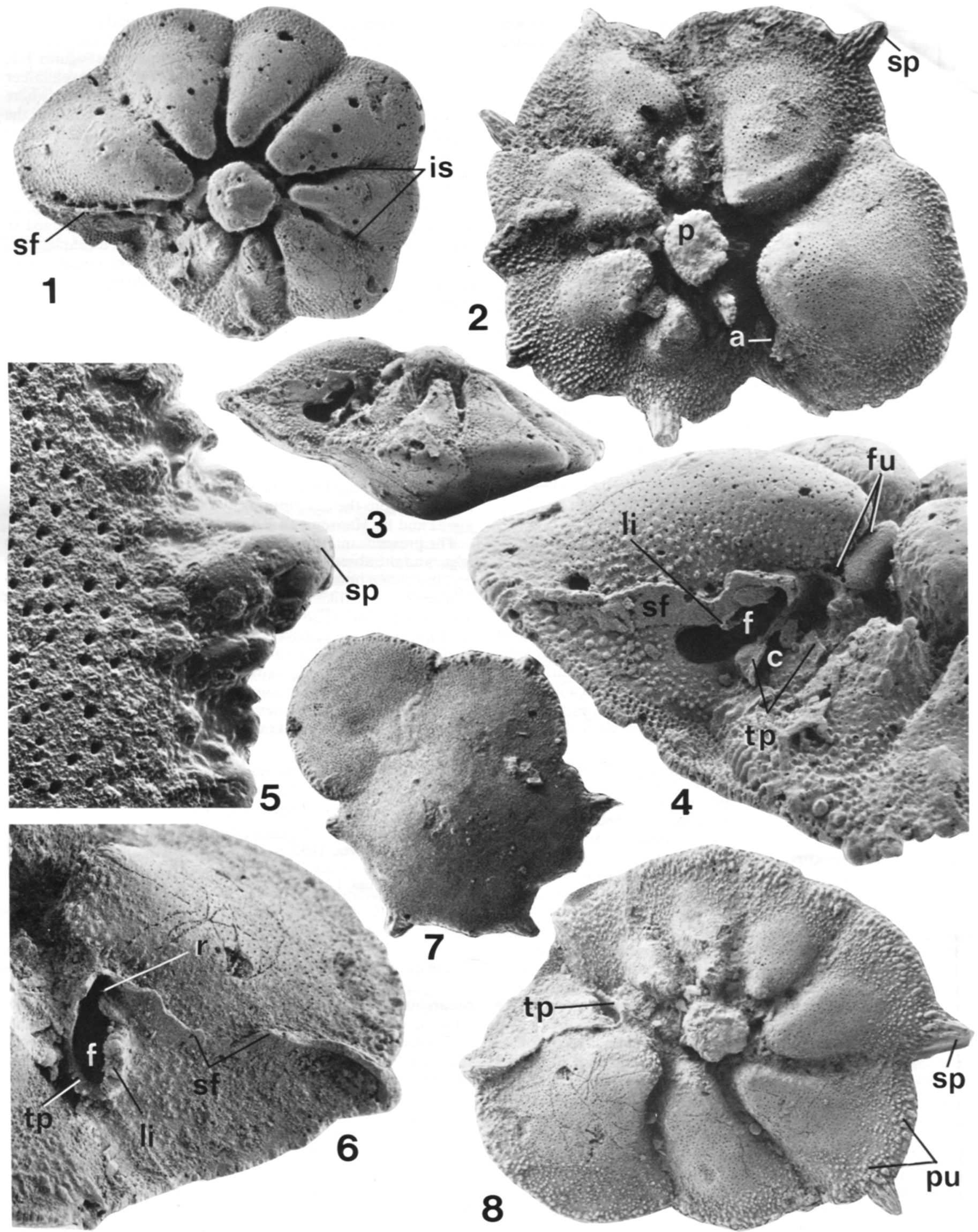
1.7) the spinose peripheral projections covered by pustules and radial ridges. These projections are solid and imperforate (Figure 1.5 ) and are thus pseudospines (see Glossary). Figure 1.2 shows the thick lip or rim along the aperture and Figure 1.8 shows the septal flap and the toothplate. Figure 1.6 shows an intercameral foramen, bordered by a thick pustulate lip and the distal, slightly serrated free edge ("inner lip") of the toothplate (belonging to the same chamber). The plate is in continuation of the inner ventral chamber wall (adaxial to the distinct umbilical shoulder), attached to the dorsal end of the interiomarginal, extraumbilical aperture (now an areal foramen), and forms a space (canal) with the preceding adjacent coil. Part of the succeeding chamber's septal flap and broken-off toothplate is also shown. At the ventral end of the foramen the apertural face is bent inward. The architecture of $P$. spinigera is, therefore, the same as that of $P$. inermis.

\author{
Genus NeOROTALIA \\ Bermudez, 1952, emend. \\ NEOROTALIA MEXICANA \\ (Nuttall, 1928) emend. Poag, 1966 \\ Figures 2.1-2.9, 3
}

Rotalia mexicana NutTall, 1928 , p. 374 , Pl. 50, figs. 6-8.

Rotalia mexicana var. mecatepecensis NuTTALL, 1932, p. 26.

Neorotalia mexicana (Nuttall). BeRMUDEz, 1952, p. 75, Pl. 12, fig. 4.

Pararotalia mexicana mecatepecensis (Nuttall). REISS AND MERLING,

1958, Pl. 2, figs. 18-24, Pl. 5, figs. 19-20; HANSEN AND Reiss, 1971,

p. 335, Pl. 10, fig. 2.

Pararotalia mexicana (Nuttall). LOEBLICH AND TAPPAN, 1964, p. C612-

C613, Pl. 486, fig. 5 (lectotype); (emend.) POAG 1966, p. 414-415,

Pl. 6, figs. 11-19; LOEBLICH AND TAPPAN, 1987, p. 659, Pl. 755, figs.

15-17.

Review. - Nuttall's (1928) description is supplemented by Bermudez (1952) who emphasized, in his description of the genus Neorotalia, the presence of strong ornamentation on both sides of the test, of an umbilical "knob," which may be subdivided, and especially of intraseptal canals. The aperture is described as a simple slit between the plug and the periphery. Reiss and Merling (1958), who regarded Neorotalia as a synonym of Pararotalia, described and illustrated by microphotographs of oriented thin sections and by camera lucida drawings of dissected chambers the architecture of Pararotalia mexicana mecatepecensis, placed by Poag (1966) in Pararotalia mexicana as a forma (an invalid infrasubspecific category, according to the ICZN). The aperture is described by Reiss and Merling (1958) as interiomarginal extraumbilical with a thick, pustulate rim and the intercameral foramen as areal, due to the attachment of a toothplate, extending from the septal flap to the distal wall and cameral aperture. The toothplates, which appear s-shaped in horizontal section, are shown to be connected to each other in adaxial position and, although not mentioned in the text, to actually protrude into the aperture. A space between toothplate and adjacent coil is discernible (Pl. 2, figs. 21, 23, 24, Pl. 5, figs. $19,20)$. Noteworthy is the inward bend of the apertural face near the ventral end of the aperture (PI. 2, figs. 19, 21). The prominent shoulder, leading to the formation of a deep umbilical bowl closed by a large single or by a compound umbilical plug, is clearly shown (Pl. 2, figs. 22, 24, Pl. 5, figs. 19, 20). Of particular interest is Reiss and Merling's (1958) figure 24 on Plate 2, which shows that the deep furrow between umbilical plug and inner umbilical walls of the surrounding chambers (forming the umbilical bowl) is covered by secondary lamination with spaces in between ("umbilical cavities" in Reiss and Merling, 1958). The septal flap is shown (P1. 5, fig. 19) to be rather narrow, covering only partly the preceding, ornamented by ridges, septal face. The thick peripheral carina is shown to be dissected into large granules by thin irregular spaces that communicate in places with the interlocular spaces (Pl. 2, figs. 1923). Poag (1966) in his emended description of Pararotalia mexicana, described and illustrated the single or sometimes subdivided umbilical plug, the "granular" keel, as well as depressions, perpendicular to the sutures on the ventral side and bordered, as shown on his Plate 6 , figure 19 , by prominent thickenings. The aperture is described by Poag (1966, p. 414) as "beginning as an elongate opening at the base of the final chamber, with a lip, later becoming partially closed by a subapertural plate, leaving an elongate narrow opening completely surrounded by a thickened lip." Hansen and Reiss (1971) illustrated a horizontal section showing the internal architecture, but interpreted (like in Pararotalia) the plates in the chambers as foramenal plates connected to cover-plates (see Glossary); this is in spite of the fact that the plates appear to be each a single element protruding with a free edge into the aperture.

Observations and remarks. - The dorsal (spiral) side is strongly ornamented by very large, rounded or elongated, imperforate pustules (Figure 2.1, 2.2). The chamber periphery is covered by thick, crowded, imperforate polygonal pustules ("granules"), with thin spaces (canals) inbetween, communicating in places with the deep interlocular intraseptal spaces (Figure 2.3-2.8).

On the ventral side, the chambers possess a prominent umbilical shoulder, the inner ventral walls producing a wide and deep umbilical bowl (Figure 2.5, 2.7), closed by a cluster of lamellar piles forming a compound plug. The latter is penetrated by canals and separated from the umbilical bowl by a deep furrow (Figure 2.3-2.5, 2.7). The ventral chamber wall possesses a distinct radial shoulder, thickened by an imperforate ridge, from which ribs, normal to the suture lines, extend on both sides of the shoulder, bordering depressions or grooves communicating with the intraseptal interlocular spaces. In some specimens the chambers may be radially extended and pointed, producing a stellate equatorial outline; in these cases the ribs on the chamber surfaces, paralleling the chamber shape, produce a chevron-shaped pattern (Figure 2.4, 2.7).

Blunt, spine-shaped projections occur on the peripheral margin, generally in extension of the apertural face; these projections are imperforate, inflational features enclosing irregular radial spaces (canals) communicating with intraseptal interlocular spaces, and are thus properly described as canaliculate spines (Figure 2.5-2.9). A conspicuous feature of the test is the external closing-off by secondary lamination of the interlocular intraseptal spaces. This secondary lamination produces over the outer margins of the intraseptal spaces so-called "flying covers"

Figure 1-1, 3, 4, Pararotalia inermis (Terquem), Lutétien, Grignon, Paris Basin. 1. 898145, $\times 120$, ventral (umbilical) view with two last chambers broken off; $3,898150, \times 120$, profile view of specimen with last chamber removed; $4, \times 240$, enlargement of part of 3. 2 , $5-8$, Pararotalia spinigera (Le Calvez), Lutétien, Grignon, Paris Basin. 2, 898140, $\times 120$, ventral view; 5, 7, dorsal (spiral) view; 7, 898146, $\times 120$ 5 , enlargement of part of 7 (chamber periphery); $6,898148, \times 240$, oblique ventral view of penultimate chamber; $8,898149, \times 120$, ventral view of specimen with ultimate chamber broken off. a, aperture; $c$, canal; $f$, intercameral foramen; fu, furrow; is, intraseptal interlocular space; li, apertural lip; p, plug; pu, pustules; r, retral bend of apertural margin at ventral corner of aperture; sf, septal flap; sp, pseudospine; tp, toothplate. 


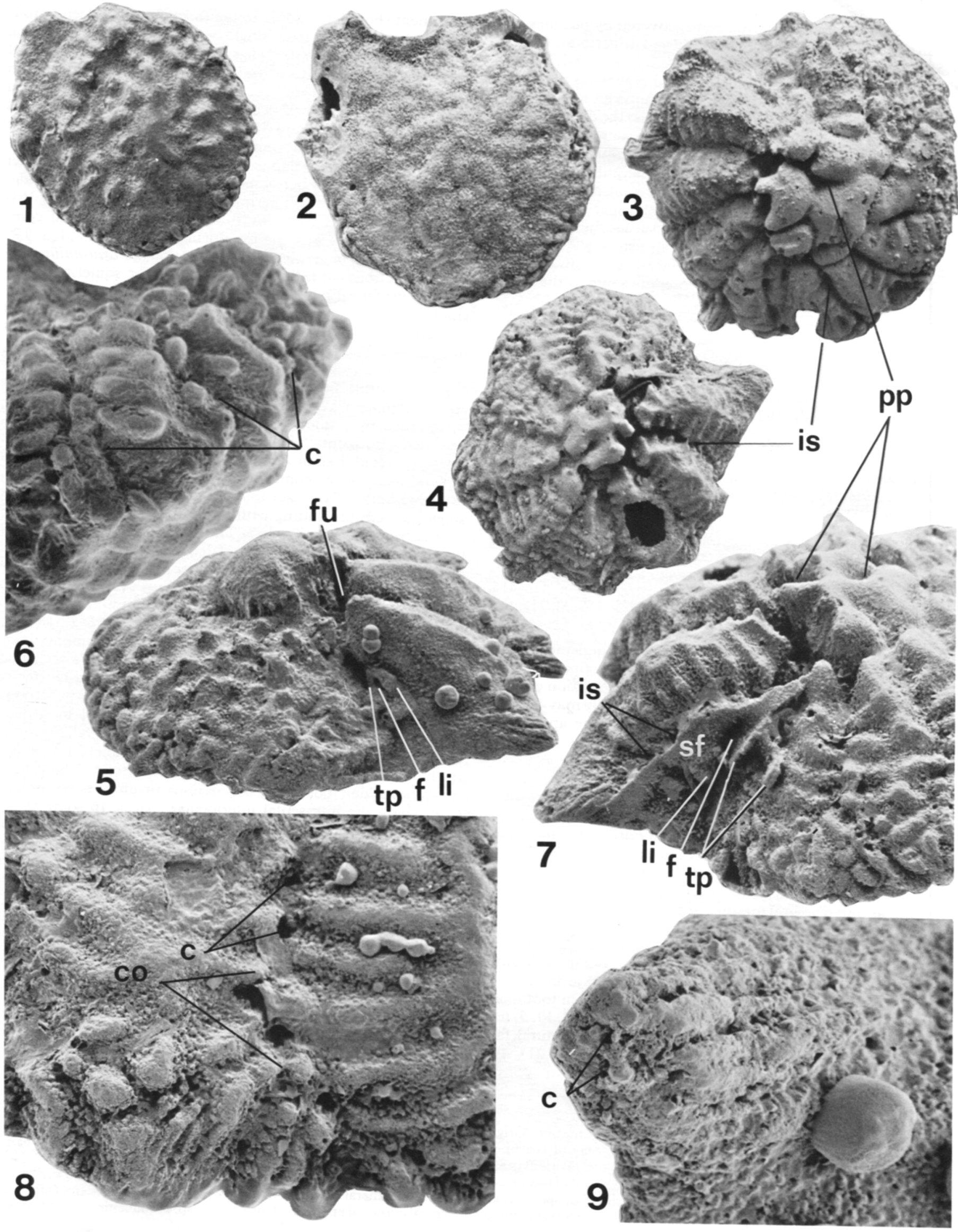


(Hottinger and Leutenegger, 1980), which leave at their margins irregularly alternating rows of canal-openings ("residual openings") into the interlocular space (Figure 2.4, 2.7, 2.8). This kind of test structure has been described by Hottinger and Leutenegger (1980) as an "enveloping canal-system" (see Glossary). As part of this system, the furrow between umbilical bowl and central umbilical plug is also gradually covered by secondary lamellae with spiral spaces or cavities between them (see Reiss and Merling, 1958, Pl. 2, fig. 24) and with canal openings to the exterior at the margins of the compound plug (Figure 2.3, 2.4, 2.7).

The primary aperture is an arched extraumbilical and interiomarginal opening, bordered by a thick, pustulate lip. The intercameral foramen is areal, modified by the attachment of a toothplate (s. str.), which extends from the septal flap into the chamber, connects with the inner ventral chamber wall, and protrudes with its free edge into the aperture (Figure 2.5, 2.7). Consecutive toothplates are interconnected in adaxial position and produce a primary spiral canal. Figure 3 is a drawing of an SEM photo of a horizontal section published by Hansen and Reiss (1971) and here reinterpreted according to our observations; it shows the septal flap, the toothplate extending from it and protruding into the aperture, whereby a canal is formed with the adjacent coil, the interlocular intraseptal spaces, and part of the enveloping canal system.

Our present findings support largely those of Reiss and Merling (1958) and of Poag (1966), but differ from those of Hansen and Reiss (1971). Neorotalia, while sharing the basic architecture, including apertural features and toothplates, with typical Pararotalia, differs from the latter by its enveloping canal-system and deserves, therefore, independent generic status.

NeOROTALIA CALCAR (d'Orbigny, 1839)

Figures 4.1-4.6, 5.1-5.4, 6.1-6.6, 7.1, 7.2

Calcarina calcar D'OrBIGNY, 1839, p. 81, Pl. 5, figs. 22-24; LE CALVEZ, 1977, p. 15, Pl. 2, figs. 1-5 (5, lectotype); HOTTINGER AND LEUTENEGGER, 1980, p. 123-124, Pl. 1, figs. 1-17; REISS AND HOTTINGER, p. 246-247, fig. G.28k-m.

Rotalia calcar (d'Orbigny). Brady, 1884, p. 709, Pl. 108, figs. 3, 4?; HOFKER, 1927, p. 37, Pl. 17, figs. 1-13.

Pararotalia calcar (d'Orbigny). ReISS AND MeRLING, 1958, p. 2-4, 8-9, $11,13,15-16$, Pl. 3, figs. 6-14; Reiss, 1963 , p. 85-86, Pl. 6, fig. 12; HOFKeR, 1970, p. 55-56, Pl. 41, figs. 1-5, HANSEN AND REISs, 1971, p. 335, Pl. 9, figs. 1-5, Pl. 10, figs. 4-6.

Rotalia defrancei (d'Orbigny). Möвrus, 1880, p. 104-105, Pl. 14, figs. $1-7$.

Review. - The canal-system of this species was already partly described and illustrated by Möbius (1880) and by Hofker (1927). Neither these authors nor Brady (1884), who all regarded $\mathrm{Cal}$ carina calcar as a Rotalia, described in detail the apertural and inner architectural features. These features were described and illustrated by microphotographs of oriented thin sections by Reiss and Merling (1958): a septal flap and intraseptal interlocular spaces (Pl. 3, fig. 11), peripheral "tubulated spines" (Pl. 3 , figs. 11, 13, 14), as well as "umbilical cavities interrupted by pillars" and due to nonadherence of consecutive outer lamellae on the ventral side (PI. 3, figs. 6, 8-10) were reported. An umbilical shoulder forming an umbilical bowl was shown,

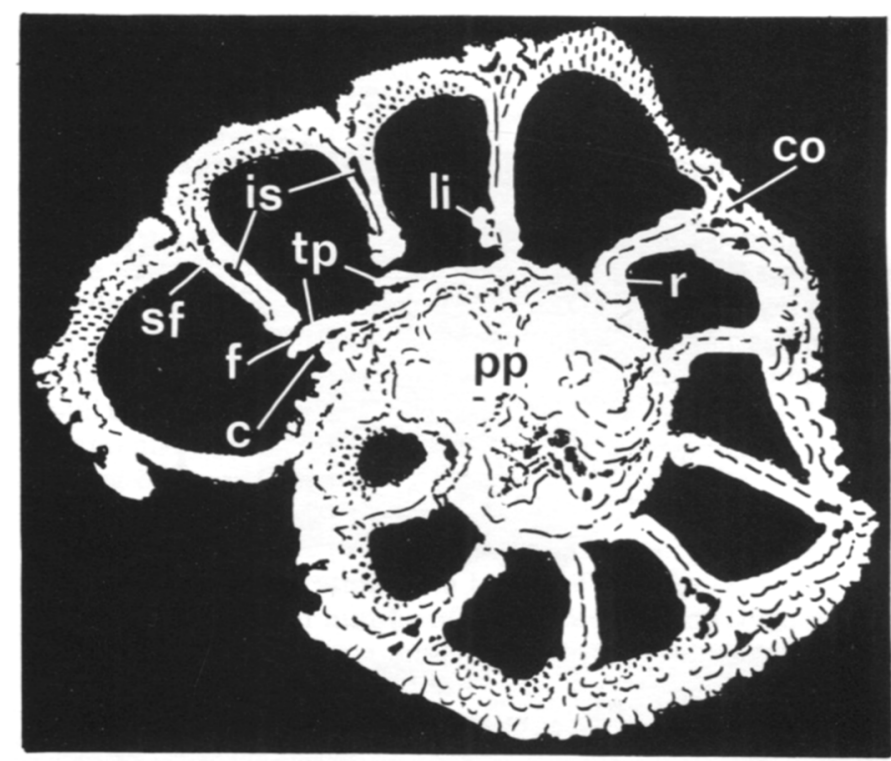

FIGURE 3-Neorotalia mexicana (Nuttall), Lower Miocene, Victoria, Australia. Reinterpreted drawings of an SEM photo of a horizontal section (from Hansen and Reiss, 1971), ×94. c, canal (formed by toothplate); co, cover of interlocular space (enveloping system); $f$, intercameral foramen; is, intraseptal interlocular space; li, apertural lip; pp, compound plug; r, retral bend; sf, septal flap; tp, toothplate.

as well as the furrow between the inner umbilical walls and the multiple lamellar piles closing the bowl being secondarily covered by outer lamellae (Pl. 3, fig. 6). The aperture was described as similar to that of Pararotalia mexicana mecatepecensis, hence interiomarginal extraumbilical, extending slightly towards the periphery and bordered by a thick lip. The presence of a toothplate (s.l) was described and the latter actually illustrated (though not described) as protruding into the aperture and forming a space between it and the adjacent coil (Pl. 3, figs. 6, 11). In view of their findings, Reiss and Merling (1958) transferred C. calcar to the genus Pararotalia.

Hofker (1970) followed this usage, but drew attention to the presence of two kinds of apertures, i.e., a large areal one, bordered by a thick lip, typical of Pararotalia, and some irregular, small ones without lips in interiomarginal position, resembling, in a "primitive" manner, apertures of Calcarina. Hofker (1970) believed, therefore, $\boldsymbol{P}$. calcar to be a link between Pararotalia and Calcarina.

Hansen and Reiss (1971) described the internal plates as foramenal plates connected with cover-plates (see Glossary), although their SEM photos of sections show clearly that each plate is a single element extending from the septal flap, connected to the inner ventral chamber wall, and protruding into the aperture, a space (canal) being formed between the adaxially interconnected plates and the adjacent coil. The chevron-shaped pattern of ridges thickened by secondary lamination was described and illustrated. It was emphasized that the latter covers the test in such a manner that "the interlocular spaces are bridged over

Figure 2-1-9, Neorotalia mexicana (Nuttall), Lower Miocene, Victoria, Australia. 1, 2, dorsal (spiral) views; $1,898156, \times 60,2,898155, \times 60$; 3,4 , ventral views; $3,898160, \times 60 ; 4,898151, \times 60 ; 5,6,7$, oblique ventral views; 5,898159 , $\times 120$, ultimate chamber broken off; 6, 898126, $\times 240$, part of peripheral margin; 7,898154, $\times 120$, part of specimen with ultimate chamber broken off; 8, 898161, $\times 240$, ventral view, part of peripheral margin; 9, 898159, $\times 600$, canaliculate peripheral spine. c, canal, canal openings; co, cover of interlocular space (enveloping system); f, intercameral foramen; fu, furrow; is, intraseptal interlocular space; li, apertural lip; pp, compound plug with canals; sf, septal flap; tp, toothplate. Note radial chamber shoulders and chevron-shaped ornamentational pattern in $3,4,7$. 

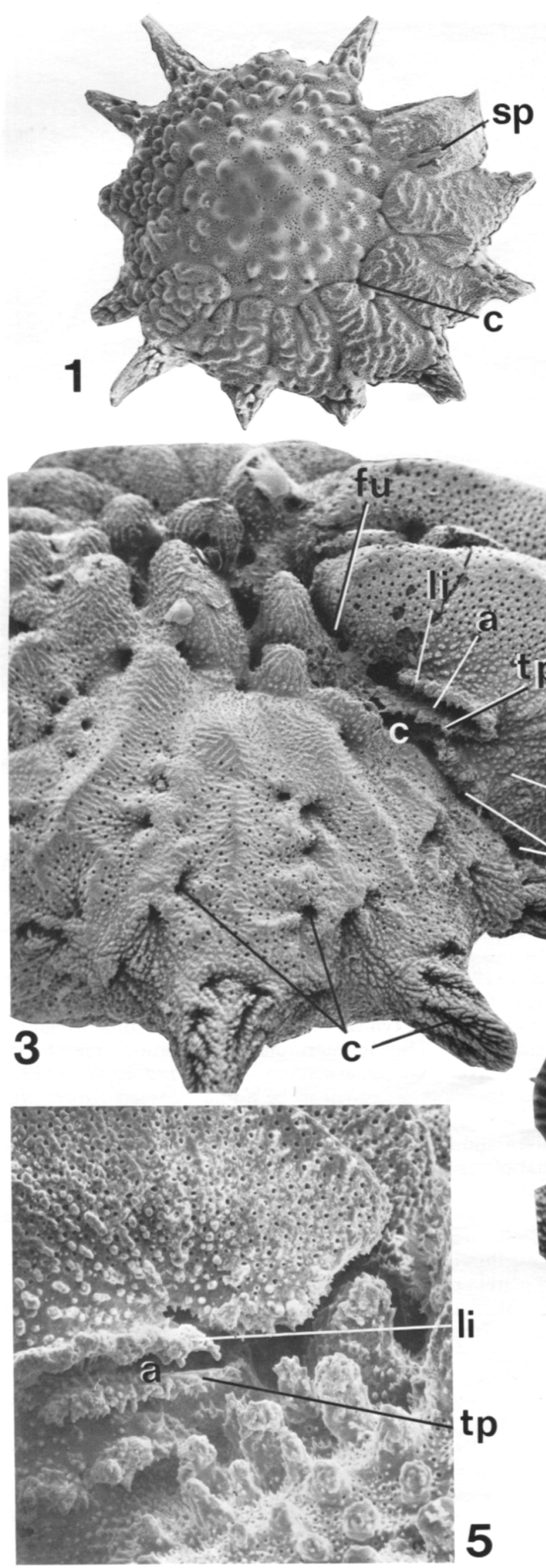
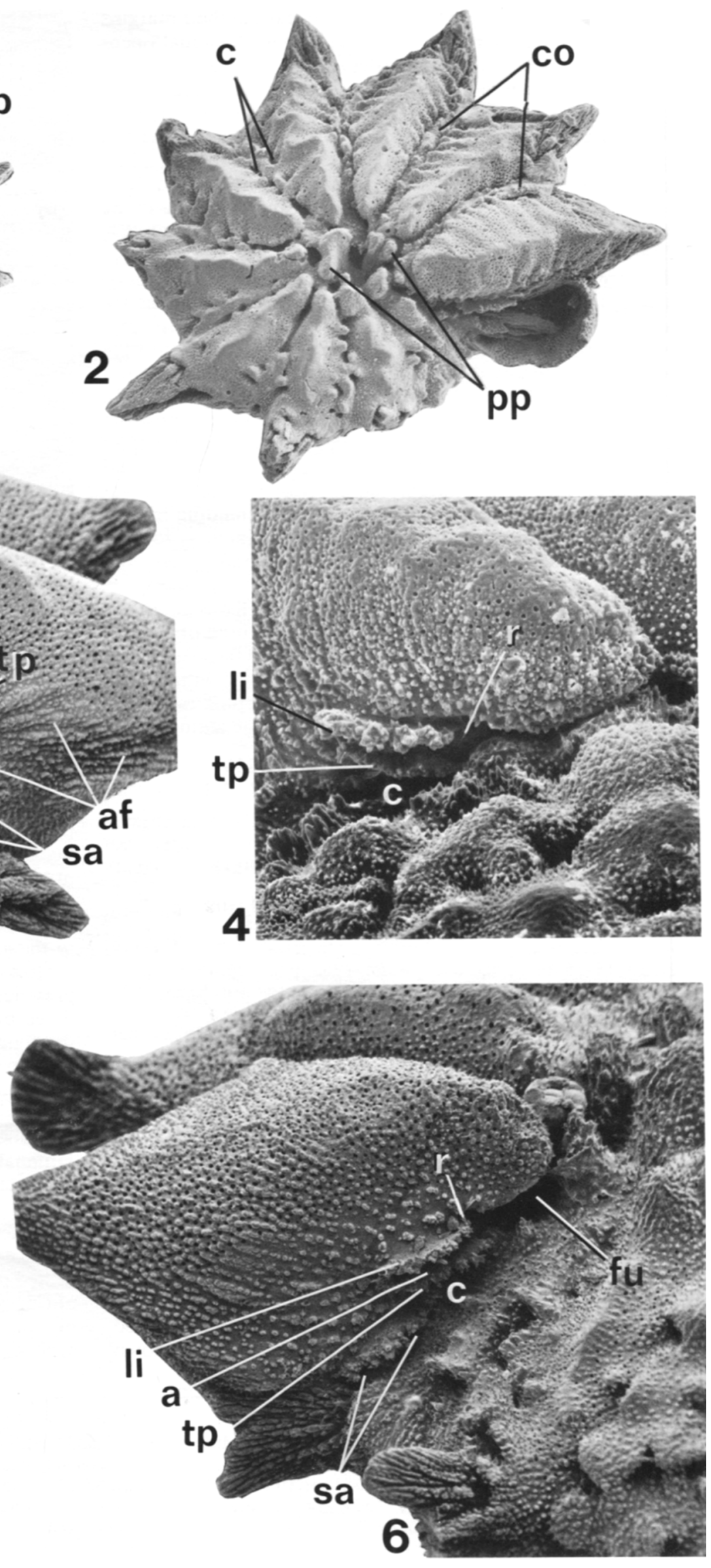
and cavities are trapped," communicating with the outside "through narrow canals leading into the peripheral spines." This is, in fact, the "enveloping canal-system" with "flying covers" described and illustrated in great detail by Hottinger and Leutenegger (1980). The "flying covers" are formed by outer lamellae that cover externally the interlocular spaces and are folded into the latter in a manner that produces funnel-like invaginations, alternating in position opposite each other at the margins of the cover and putting in communication the interlocular spaces with the exterior ("residual openings").

Hottinger and Leutenegger (1980) denied the presence of a "hooked umbilical chamber extension" (i.e., a toothplate), which can be seen, however, in their Plate 1 , figures 16,17 . On the other hand, Hottinger and Leutenegger (1980) regarded the inner ventral chamber wall (adaxial from the umbilical shoulder) as an "umbilical plate," forming an "interlocular space" subsequently transformed into a spiral canal. Multiple intercameral foramina were described (P1. 1, fig. 16), although a single, large elongated and extraumbilical opening with a serrated lip was shown as the intercameral foramen (P1. 1, figs. 11, 12). Mainly on the basis of the enveloping canal-system, as well as of the reported multiple intercameral foramina, Hottinger and Leutenegger (1980) attributed the species calcar again to Calcarina, a usage followed by Reiss and Hottinger (1984).

Observations and remarks. - The chambers are radially elongated and peripherally pointed, with spinose projections giving the test its typical stellate equatorial outline (Figure 4.1, 4.2). The dorsal (spiral) side is covered with large inflational pustules, as well as, in later chambers, by irregularly elongate, sometimes vermiculate pustules (Figure 4.1). On the ventral (umbilical) side each chamber shows a prominent radial shoulder. An umbilical shoulder leads to the formation of a deep umbilical bowl by the inner ventral chamber walls (Figure 4.2, 4.3). The sutures are deeply sunken, forming the interlocular intraseptal spaces, which are covered externally by secondary lamination forming the flying covers with their bordering openings of the enveloping canal-system (Figure 4.2, 4.3). The openings of the covers correspond closely in position to the grooves running along prominent ribs from the radial imperforate chamber shoulder, and nearly normal to it, into the intraseptal spaces (compare also Hottinger and Leutenegger, 1980). Grooves and adjoining ribs parallel roughly the peripheral chamber shape and form thus a chevron-shaped pattern (Figure 4.2). Secondary lamination blurs the ornamentation and covers part of the canal openings along the flying covers, but produces new openings in irregular sutural and radial position (Figure 4.2, 4.3).

The umbilical bowl is closed by a cluster of prominent inflational piles externally expressed as thick pustules, with distinct canals between them (Figure 4.2, 4.3). The furrow ("interlocular space" in Hottinger and Leutenegger, 1980) produced by the inner ventral chamber walls forming the umbilical bowl and connected with the intraseptal interlocular spaces (Figure 4.2) is gradually covered by partly nonadhering secondary lamellae (Figure 4.3) and converted into a spiral canal. Spaces between the ventral piles are covered in the same manner, producing the "umbilical cavities" reported by Reiss and Merling (1958, Pl. 3 , fig. 10). The distal chamber face is roughly triangular in shape, densely covered by minute rounded to elongate pustules and riblets, aligned more or less in the direction of the periphery and of the radial chamber shoulder (Figure 4.4-4.6). Secondary lamination enhances and modifies this ornamentation in later instars and produces, together with ribs and adjoining grooves running towards the intraseptal spaces, the characteristic chevron-shaped ornamentational pattern. The spinose projections of the shell are built up stepwise by radial folds of secondary lamellae glued at first against the peripheral radial ridges on the apertural face of the penultimate chamber and later against the previous folds of secondary outer lamellae. Thus, long inflational canaliculate spines are produced housing radially diverging and anastomosing canals with bordering minute spikes, extending every intraseptal interlocular space in radial direction (Figure 4.1-4.3). Chambers are built against or around the canaliculate spines of the preceding coil, which puts the spine canal system in communication with both the exterior on the dorsal side and the chamber lumina of the succeeding coil (Figures 4.1, 6.1). All inflational ornamentational features are covered by minute ridges (Figure 4.1).

The primary cameral aperture is a slightly arched interiomarginal, extraumbilical slit, slightly extended towards the periphery and bordered by a strongly pustulate lip (Figure 4.4 4.6). The distinctly serrated free edge of a toothplate, connected to the apertural lip at its distal corner, protrudes into the aperture and produces a space (canal) between plate and adjacent coil (Figure 4.4-4.6). The apertural face is bent backwards at the proximal end of the apertural lip (Figure 4.5, 4.6). Between the distal end of the main chamber aperture and the periphery, irregular openings in interiomarginal position, bordered by pustules and spinules, can be observed, especially in later chambers of well-preserved specimens (Figure 4.3, 4.6). They are regarded here as supplementary apertures.

Dissected specimens (Figures 5, 6) show the test architecture and structure in detail. The imperforate toothplate is seen to extend from the narrow septal flap through the chamber to the interiomarginal aperture, to protrude into the latter, thus restricting it, and to produce with the adjacent coil a primary spiral umbilical canal, communicating with the chamber lumen, as well as with the furrow (Figure 5.1-5.4). Attachment of the toothplate to the septal flap leads to the intercameral foramen, which preserves the pustulate lip of the aperture, to become truly areal. The retral bend of the apertural face at the ventral corner of the aperture, mentioned above in Pararotalia inermis and in Neorotalia mexicana, is shown in $N$. calcar to extend finger-like into the chamber lumen (Figure 5.2-5.4). The covers of the intraseptal interlocular spaces with their openings to the exterior are shown in Figure 5.3, 5.4. The canaliculate spines are incorporated into the succeeding coil on the spiral side as the result of chambers being built against or around the spine (Figure 6.1-6.3). The relationship of toothplate to septal flap and to the spiral canal-system, the intercameral foramina and apertural lips, as well as the intraseptal interlocular spaces and their covers of the enveloping canal system are also shown in Figure 6.3-6.6. The SEM photo of a sectioned araldite cast (Figure 6.6) shows the main chamber lumina and intercameral foramina, as well as, adjoining the latter, the toothplates, which

Figure 4-1-6, Neorotalia calcar (d'Orbigny), Recent, Gulf of Aqaba, Red Sea, 1.5-6.0 m depth. 1, 7604-G, × 75, dorsal view, note ornamentation; $2,7645-G, \times 110$, ventral view, note ornamentation; 3-6, oblique ventral views; 3,875222 , $\times 240$, apertural face and part of adjacent coil, note canaliculate spines; 4, 7641-G, $\times 400$, apertural face of ultimate chamber; $5,7613-\mathrm{G}, \times 370$, apertural face of ultimate chamber; 6,875227 , $\times 240$, apertural face of ultimate chamber and part of adjacent coil. a, aperture; af, apertural (distal) face; c, canal openings; co, cover of intraseptal interlocular space (enveloping system); fu, furrow; li, apertural lip; pp, multiple piles with canals in between; r, retral bend; sa, supplementary apertures; $s p$, canaliculate spine; tp, toothplate. 

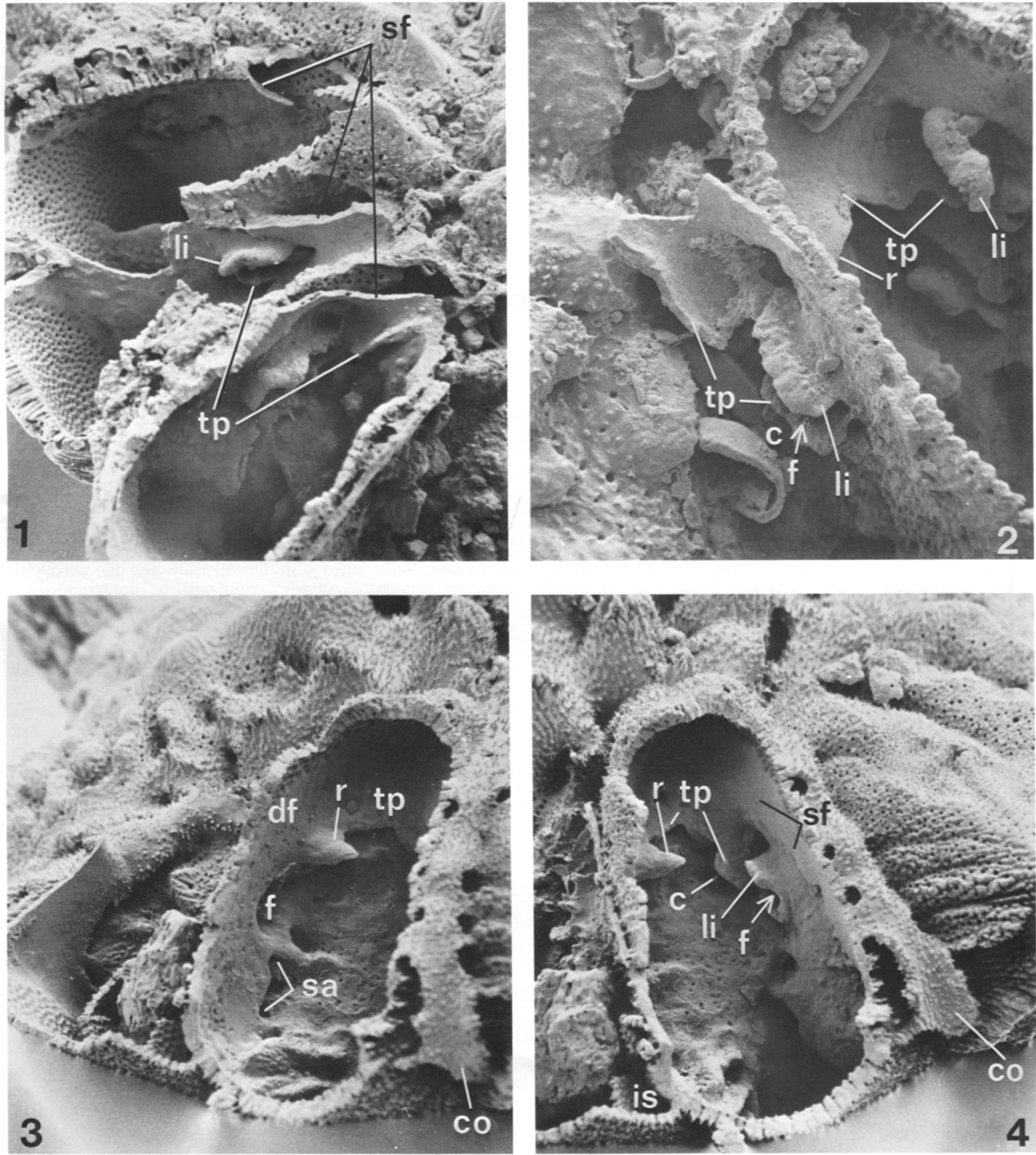

Figure 5-1-4, Neorotalia calcar (d'Orbigny), Recent, Gulf of Aqaba, Red Sea, $1.5 \mathrm{~m}$. Internal views of ventrally dissected specimens. 1, 898129 , $\times 240 ; 2,875225, \times 600 ; 3,898127, \times 240 ; 4,898128, \times 240 ; 3,4$, same chambers seen from different angles. c, canal; co, cover of intraseptal interlocular space (enveloping system); df, distal chamber wall; $f$, intercameral foramen; is, intraseptal interlocular space; li, apertural lip; $r$, retral bend at ventral end of aperture; sa, supplementary apertures; sf, septal flap; tp, toothplate. 
are adaxially connected in successive chambers, producing a spiral umbilical canal. The latter communicates through narrow openings with the furrow that borders the umbilical bowl and is converted into a spiral canal continuous with the intraseptal spaces. What appear to be multiple supplementary foramina are also shown at the lower margin of Figure 6.6.

A reinterpreted drawing of an SEM photo of a horizontal section of $N$. calcar, published by Hansen and Reiss (1971), is shown in Figure 7.1, 7.2. The toothplates of consecutive chambers are seen to protrude into the main apertures and to be interconnected adaxially, thus producing the spiral umbilical canal. It is noteworthy that the toothplates are seen to be in continuation of the wedging out, inner ventral, perforate and laminated chamber wall where the spiral toothplate canal passes into the spiral furrow around the multiple plugs (Figure 7.2 and compare Figure 6.6). The retral bend at the ventral end of the aperture is clearly seen. It is of interest to note that in this spot the thick, pustulate lip does not border the aperture like it does along most of the slightly forward-bent apertural margin. The enveloping canal-system is shown at the outer margins of the interlocular spaces, and so is the structure of the canaliculate spines, communicating with the remainder of the canal system.

The present description supplements and modifies to some extent that of Hottinger and Leutenegger (1980) and indicates that the general architecture and test structure of Calcarina calcar d'Orbigny is identical with that of Neorotalia mexicana. An exception appears to be the supplementary apertures of NeOrotalia calcar. However, these apertures are small and irregular, lack peristomal thickenings, and are observed only in well-preserved adult chambers. Presence or absence of such supplementary apertures is not definitely proven in the fossil tests of Neorotalia mexicana. Moreover, presence or absence of supplementary apertures in the distal face in addition to a main aperture in other rotaliacean genera is not regarded by the present authors as being of generic value (Hottinger et al., in press). It is doubtful whether the interiomarginal supplementary apertures of $N$. calcar are related to the multiple, interioareal primary apertures of the genus Calcarina, as assumed by Hofker (1970) (see below).

\section{NEOROTALIA VIENNOTI (Greig, 1935)}

Figure 8.1, 8.2

Rotalia viennoti GreIG, 1935, p. 524, Pl. 58, figs. 1-14.

Neorotalia viennoti (Greig). BERMUDEZ, 1952, p. 19.

Pararotalia viennoti (Greig). Reiss AND MerLING, 1958, p. 1, Pl. 3, figs. 1-5.

Review. - Rotalia viennoti has been compared with Rotalia calcar by Greig (1935), who suggested that both of them should be included perhaps in a new genus, different from Rotalia. It was included by Bermudez (1952) in his genus Neorotalia. Reiss and Merling (1958) included $R$. viennoti in Pararotalia. For these reasons we have reexamined topotypes of this species.

In his original description, Greig (1935) emphasized the heavy ornamentation by pustules of both sides of the test and especially those forming "vertical pillars" in the center of the test, possibly having a function in supporting and strengthening of the test. Greig also reported a "typical canal-system." The aperture was described as "peripheral and slightly ventral, near the base of the apertural face ... consisting of a plain slit ... in the adult of irregular openings ... their configuration being controlled ... by the pustular arrangement of the previous coil." Greig's Plate 58 , figure 1 strongly suggests an extraumbilical aperture restricted by a plate. The umbilical bowl is shown on Plate 58, figures 1,14 ; in the latter (a vertical section) an internal plate forming a space with the adjacent coil is well apparent.
Reiss and Merling (1958) examined specimens identified as Rotalia viennoti from the Middle Eocene, which seem closely related to, if not conspecific with, the types from the Oligocene. They described and illustrated in thin sections the extraumbilical interiomarginal aperture, a toothplate, intraseptal interlocular spaces, the cluster of thick "pillars" in the axial region, as well as the heavy pustules on both sides of the test. By comparison with Rotalia mexicana mecatepecensis, included in Pararotalia, Reiss and Merling (1958) attributed $R$. viennoti to this latter genus.

Observations and remarks. - The test is heavily pustulate on both sides and on the periphery and especially in the central ventral region (Figure 8.1). These pustules represent the terminations of the massive inflational piles forming the compound axial plug (see also Greig, 1935; Reiss and Merling, 1958). The ornamentation is enhanced by thick secondary lamination, which blurs the radial-chamber shoulders visible in the last few chambers (Figure 8.1), as well as the deeply sunken sutures forming the intraseptal interlocular spaces (Figure 8.1, 8.2). An enveloping canal system due to secondary lamination is present, the covers at the margin of the interlocular spaces with their openings to the exterior visible only in ontogenetically late chambers, where heavy ornamentation does not hide them (Figure 8.1).

The rather narrow septal flap extends into a toothplate; the latter is connected to the inner ventral chamber wall (forming the largely hidden umbilical bowl) and protrudes with a distinctly serrated free edge into the interiomarginal extraumbilical aperture (bordered by a heavily pustulate lip), thus producing a spiral umbilical canal (Figure 8.2). Thick pustules present on the previous coil opposite the aperture (Figure 8.1) may lead the latter to appear in the light-microscope as multiple (see Greig, 1935). The architecture of Rotalia viennoti is thus identical with that of Neorotalia mexicana and Neorotalia calcar and is, therefore, included in Neorotalia, in agreement with Bermudez (1952).

\section{Family Calcarinidae Schwager, 1876 \\ Genus Calcarina d'Orbigny, 1826 \\ CALCARINA SPENGLERI (Gmelin, 1791)}

Figure 8.3, 8.7

Nautilus spengleri GMELIN, 1788-1793, Vol. 1, No. 6.

Calcarina spengleri (Gmelin). CuSHMAN, 1927, p. 72, Pl. 31, fig. 2; HOFKER, 1927, p. 45, Pl. 2, figs. 3-6, 8-10; HANSEN AND REISS, 1971 , p. 336, Pl. 11, figs. 1-6, Pl. 12, figs. 1-5; HOTTINGER AND LEUTENEGGER, 1980, p. 124-125, Pl. 6, figs. 1-13, Pl. 7, figs. 1-3, text-fig. 2; HANSEN, 1981, Pl. 4, figs. 1, 2, (neotype), Pl. 5, figs. 1--6.

Calcarina mayori Cushman. ReIss AND MERING, 1958, PI. 3, figs. 17 , 18, Pl. 4, figs. 1-4.

Review. - The type-species of the genus Calcarina has been extensively discussed in the literature (see references above with bibliography) and only a few points should be raised here, pertaining to differences from Neorotalia.

Nearly all authors have described the aperture as multiple rounded openings, surrounded by thick rims, interioareal in position. Only Reiss and Merling (1958) have described the aperture as a "strongly indented interiomarginal one, part of the indentations coalescing and forming 'pores'." Scanning electron microscopy (Hansen and Reiss, 1971; Hottinger and Leutenegger, 1980) disproved this latter description and showed the multiple apertures surrounded by thick rims. A toothplate (s.l.) was recorded by Reiss and Merling (1958) "very near the adjacent coil" and Hansen and Reiss (1971) reported a foramenal plate and cover plate in early stages only. No internal plate was observed by Hottinger and Leutenegger (1980). Reiss and Merling (1958) showed in thin sections the presence of intraseptal in- 

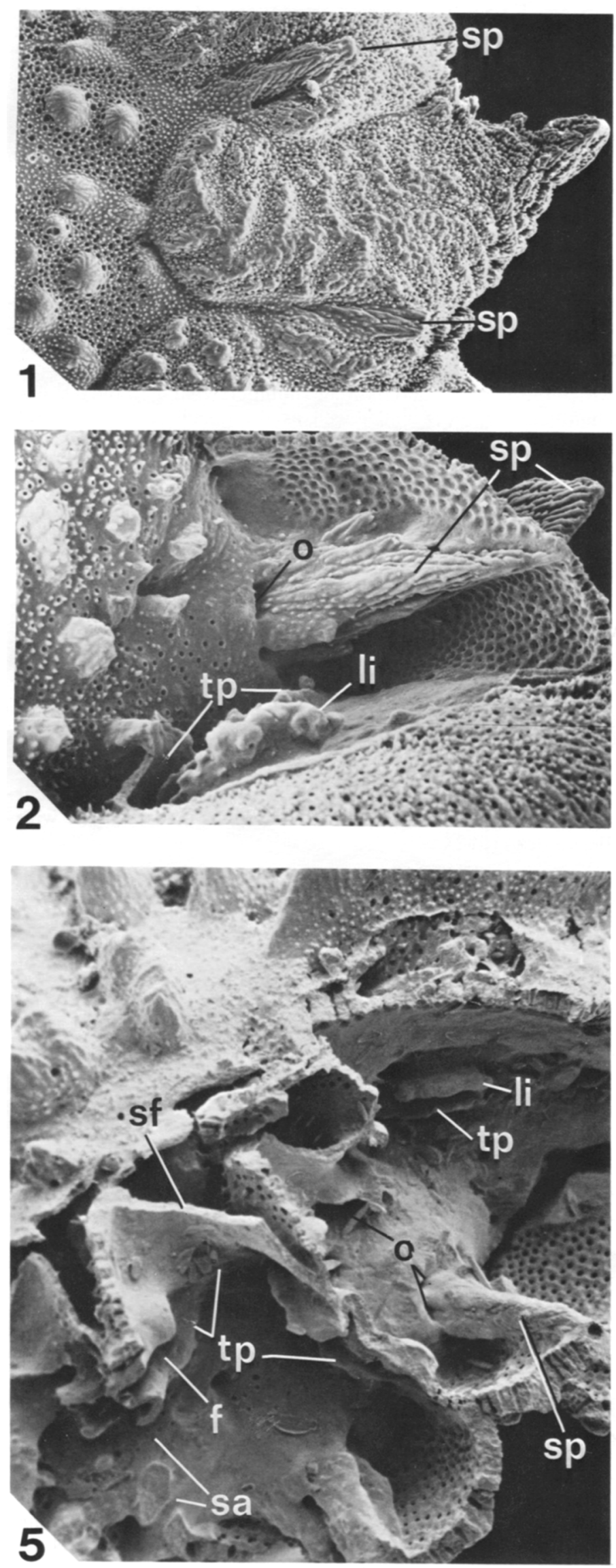
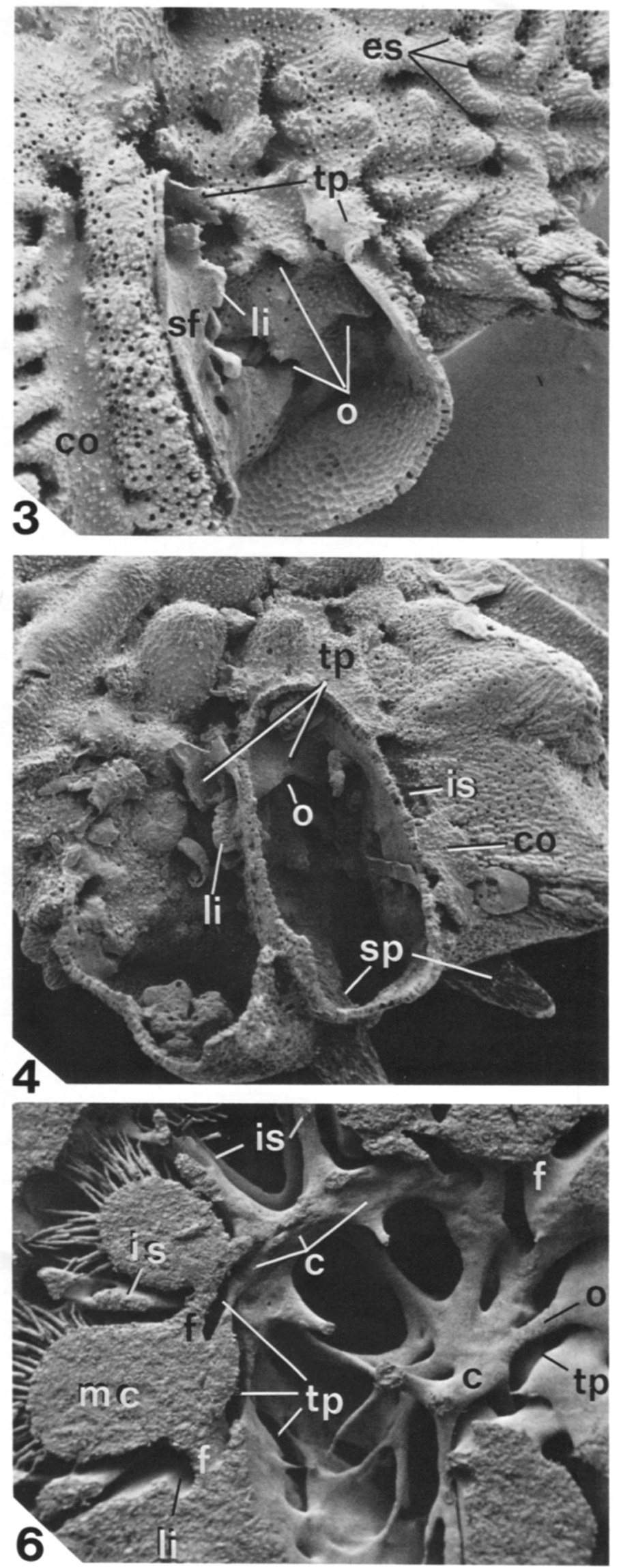
terlocular spaces, as well as of "umbilical and intramural cavities" interrupted by numerous "pillars," produced by secondary lamination in the ventral chamber walls of the test. This corresponds to the enveloping canal system described in detail by Hottinger and Leutenegger (1980). The structure of the canaliculate spines was shown by these latter authors (see also Hansen and Reiss, 1971).

Observations and remarks. - The accompanying Figure 8.4 and 8.7 demonstrates clearly the multiple, irregularly rounded apertures with thick peristomal lips or rims, preserved as such when converted into intercameral foramina. There is no foramenal or cover plate present and neither is there a toothplate with free edge. On the other hand, a forward extension of the septal flap, very near the adjacent coil, can be observed (Figure 8.7) and is best described as an umbilical plate. It produces part of the spiral umbilical canal described by Hottinger and Leutenegger (1980). The canal openings of the enveloping system around the heavy pustules on the ventral side are shown in Figure 8.5 and the club-shaped canaliculate spines in Figure 8.3-8.6. Particularly well developed spikes at the margins of canal openings of the chamber wall and in the canaliculate spines are shown in figure 8.6.

Calcarina differs, therefore, considerably from Neorotalia mainly by the presence of multiple, interioareal main apertures surrounded by thick rims, by the absence of a toothplate (s. str.) with a free edge, as well as by the presence of an umbilical plate.

\section{DISCUSSION AND CONCLUSIONS}

Reexamination of the type-species of the genera Pararotalia Le Calvez, 1949, and Neorotalia Bermudez, 1952, shows them to possess the same basic architecture, including interconnected toothplates with a free edge, producing a spiral canal, and a single interiomarginal main aperture. However, Neorotalia differs from Pararotalia in possessing in addition an enveloping canal system, produced by secondary lamination, and must, therefore, be regarded as a valid independent genus. Calcarina calcar d'Orbigny, 1826, placed by some authors in Pararotalia, has the same canal system, toothplates, and apertural features as Neorotalia and must be placed in this latter genus. This despite the fact that $N$. calcar possesses irregular supplementary apertures. The type-species of Calcarina d'Orbigny, 1826, also characterized by an enveloping canal system, possesses, however, multiple primary interioareal chamber apertures surrounded by thick rims and an umbilical plate, but lacks the toothplate with free edge, typical of Pararotalia and Neorotalia.

Figure 7-1, 2, Neorotalia calcar (d'Orbigny), Recent, Gulf of Aqaba, Red Sea. Reinterpreted drawing of an SEM photo of a horizontal section (from Hansen and Reiss, 1971), $\times 185$. 2, partial enlargement of $1, \times 500$. c, canal; co, cover on intraseptal interlocular space (enveloping system); df, distal chamber wall; $f$ intercameral foramen; is, intraseptal interlocular space; li, apertural lip; mc, main chamber lumen; pp, multiple piles; $r$, retral bend; sf, septal flap; spc, canaliculate spines and canals; tp, toothplate, $w$, inner ventral, perforate chamber wall coating toothplate at their junction.
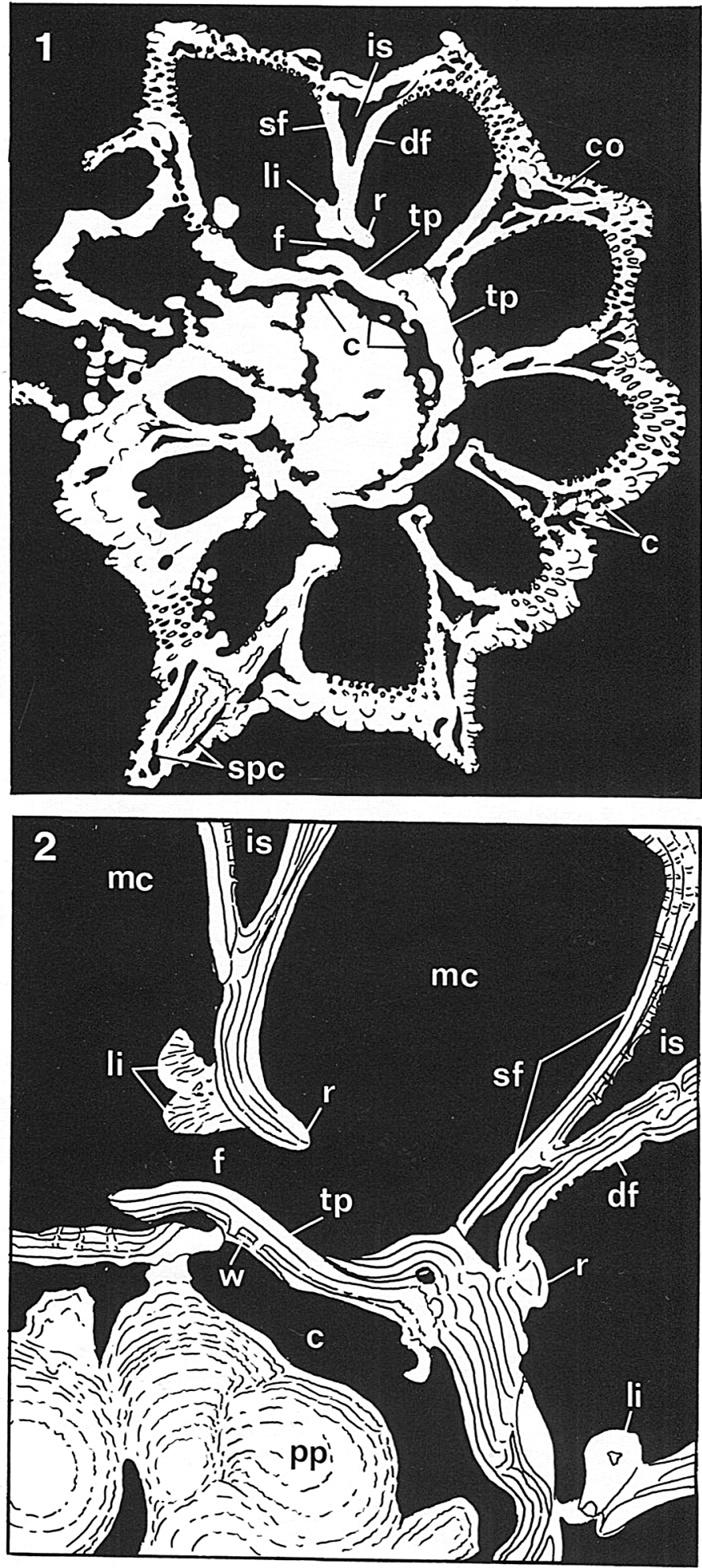

Figure 6-1-6, Neorotalia calcar (d'Orbigny). 1-5, Recent, Gulf of Aqaba, Red Sea, 1.5-6 m; 6, Recent, Keij Island, Indonesia. 1, 7605-G, $\times 220$, part of dorsal view showing incorporation of canaliculate spines from preceding coil; $2-5$, internal views of ventrally dissected chambers: $2,7640-\mathrm{G}, \times 400$, note incorporated canaliculate spine; $3,898135, \times 240 ; 4,875224, \times 240 ; 5,898133, \times 240 ; 6$, horizontal section of araldite cast (shell material dissolved), note transition from toothplate canal to furrow canal in upper part of picture. c, canal; co, cover of intraseptal interlocular space; es, enveloping canal-system; f, intercameral foramen; is, intraseptal interlocular space; li, apertural lip; mc, main chamber lumen; o, opening between main chamber lumen and canal-system; sa, supplementary aperture; sf, septal flap; sp, spine; tp, toothplate. 


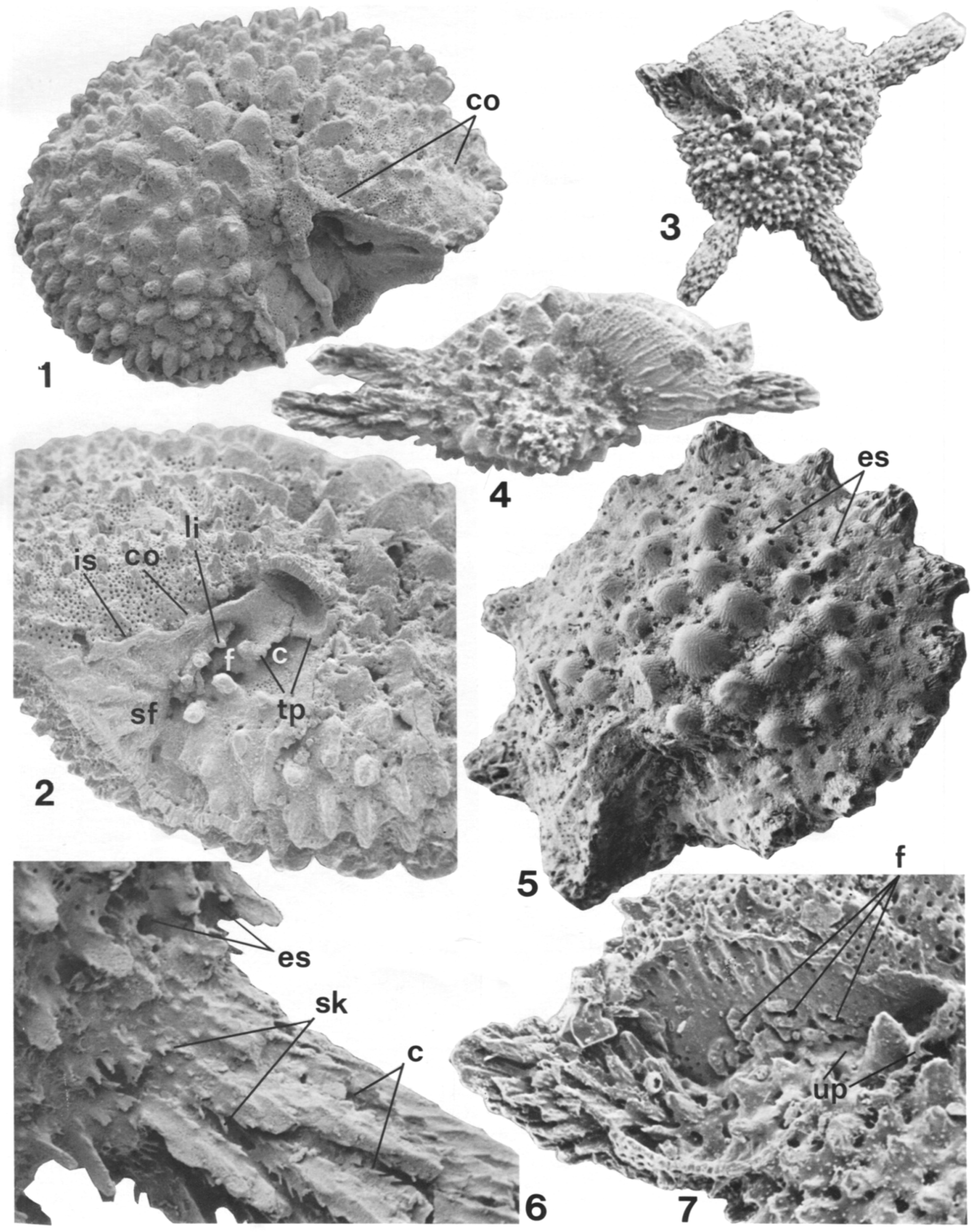


The earliest, toothplate-bearing pararotaliids were observed in thin sections of hard rocks at the base of the Late Cretaceous limestone sequence of Terradets Gorge, Montsech, Lerida Province, northern Spain (Hottinger and Rosell, 1973), level MS27, of Coniacian or Early Santonian age. They co-occur with true Rotalia and other rotaliid genera, like Kathina and Orbitokathina.

The derivation of all rotaliids from Pararotalia advocated by some authors (see also Reiss and Merling, 1958) is, thus, questionable. The differences between the Rotaliinae and the Pararotaliinae with regard to toothplates, umbilical plates, folia, and canal-systems are so great that an independent development of these groups in the Turonian or earlier must be assumed. For the same reasons, it would be probably appropriate to consider the Pararotaliinae Reiss, 1963, and the Cuvillierininae Loeblich and Tappan, 1964 (as well as the Ammoniinae Saidova, 1981, with foramenal and cover plates) as separate families, and not as subfamilies of the Rotaliidae Ehrenberg, 1839 (see Loeblich and Tappan, 1987).

The functional significance of differentiation into dense endoplasm in the main chamber lumina and rhizopodial ectoplasm (with different organelles and inclusions) in canal-systems has been discussed by Hottinger and Dreher (1974), Hottinger (1978), Hottinger and Leutenegger (1980), and Reiss and Hottinger (1984). Basically, canal-systems serve as bypasses of endoplasm-containing main chamber-lumina and intercameral foramina, thus connecting functional ectoplasm deep inside the test directly with the exterior. This is particularly advantageous to the individual (e.g., with regard to motility) under conditions of external stress.

Although test geometry is quite different, toothplates in the Neorotaliinae resemble those of certain Buliminidae, where they form a kind of axial canal, regarded to contain ectoplasm active in oxygen uptake under low-oxygen conditions (Veerhallen, 1986). Cytoplasmic differentiation of canal-cytoplasm in NeOrotalia calcar has been shown by Hottinger and Leutenegger (1980). With regard to the enveloping canal-system, it seems that it plays an important role in both Neorotalia and Calcarina in facilitating pseudopodial hold-fast to solid substrate or plants in the high-energy, shallow-water environments of the photic zone, to which these symbiontic diatom-bearing genera are confined (Reiss and Hottinger, 1984). Geological evidence suggests that the Late Cretaceous-Miocene Pararotalia was characteristic of calmer waters. Analogies, homologies, and functional significance of foraminiferal test structures remain challenging topics for further studies on living individuals.

\section{ACKNOWLEDGMENTS}

The authors are indebted to $\mathbf{M}$. Langer and $\mathbf{M}$. Düggelin (University of Basel) and to M. Dvoraczek (Geological Survey of Israel, Jerusalem) for assistance in scanning electron microscopy. A. R. Loeblich, Jr. and B. K. Sen Gupta offered constructive criticism of the manuscript. The material examined originates from collections at the University of Basel and The Hebrew University of Jerusalem. All figured specimens are deposited in the Natural History Museum of Basel.

\section{REFERENCES}

BERMUDEZ, P. J. 1952. Estudio sistematico de los foraminiferos rotaliformes. Boletin de Geologia, Venezuela, 2(4):1-230.

BraDY, H. B. 1884. Report on the foraminifera dredged by H.M.S. Challenger during the years 1873-1876. Reports of the Scientific Results of the Voyage of H.M.S. Challenger (Zoology), 9, 814 p.

BRÜNNICH, M. T. 1772. Brünnich Zoologiae Fundamenta. Hafniae et Lipsiae, Grunde i Dyeloeren, 253 p.

Cushman, J. A. 1927. An outline of a reclassification of the foraminifera. Contributions from the Cushman Laboratory for Foraminiferal Research, 3:1-105.

DeBOURLe, A. 1955. Cuvillierina eocenica, nouveau genre et nouvelle espece de foraminifêre de l'Ypresien d'Aquitaine. Compte Rendu des Séances de la Société Géologique de France, 1955:19.

Delage, Y. ANd E. Hérouard. 1896. Traité de Zoologie Concrete. 1. La Cellule et les Protozoaires. Schleicher Fréres, Paris, 584 p.

EHRENBERG, C. G. 1839. Über die Bildung der Kreidefelsen und des Kreidemergels durch unsichtbare Organismen. Physikalische Abhandlungen der Königlichen Akademie der Wissenschaften zu Berlin, 1838 [1840: separate 1839]:59-147.

GMELIN, J. F. 1788-1793. Systema naturae Linnaei, 1(6):3021-3909, Vermes (13th ed.). G. E. Beer, Lipsiae, Germania.

GreIG, D. A. 1935. Rotalia viennoti, an important foraminiferal species from Asia Minor and western Asia. Journal of Paleontology, 9: 524.

HANSEN, H. J. 1981. On Lorentz Spengler and a neotype for the foraminifer Calcarina spengleri. Bulletin of the Geological Society of Denmark, 29:191-201.

- AND Z. REISS. 1971. Electron microscopy of rotaliacean wall structures. Bulletin of the Geological Society of Denmark, 10:329346.

Hofker, J. 1927. The foraminifera of the Siboga Expedition, Pt. 1, Tinoporidae, Rotaliidae, Nummulitidae, Amphisteginidae. E. J. Brill, Leiden, $74 \mathrm{p}$

. 1951. The toothplate Foraminifera. Archives Néerlandaises de Zoologie, 8:353-372.

1957. Foraminifera from the Cretaceous of Southern Limburg, Netherlands, XXIV. The development of Pararotalia tuberculifera (Reuss). Natuurhistorisch Maandblad, 46(3-4):31-39.

. 1970. Studies of foraminifera. Part II, Systematic problems. Publicaties van het Natuurhistorisch Genootschap in Limburg, 20: $1-98$.

HOTIINGER, L. 1978. Comparative anatomy of elementary shell structures in selected large foraminifera, p. 203-266. In R. H. Hedley and C. G. Adams (eds.), Foraminifera, Vol. 3. Academic Press, Inc., London.

, AND D. DreHER. 1974. Differentiation of protoplasm in Nummulitidae (Foraminifera) from Elat, Red Sea. Marine Biology, 25:4161.

, E. HALICZ, AND Z. ReIss. In press. Architecture of Eponides and Poroeponides reexamined. Micropaleontology.

- AND S. LEUTENEGGer. 1980. The structure of calcarinid foraminifera. Schweizerische Paläontologische Abhandlungen, 101:115151.

, AND J. Rosell. 1973. El Cretacico superior del Montsec. XIII. Coloquio europeo de micropaleontologia, p. 73-85. Empresa Nacional Adaro Investigaciones Mineras S.A., Madrid.

LAMARCK, J. B. 1804. Suite des mémoires sur les fossiles des environs de Paris. Annales Museum National d'Historie Naturelle, 5:237-245.

Le Calvez, Y. 1949. Révision des foraminiféres Lutétiens du Bassin de Paris. II. Rotaliidae et familles affines. Mémoires du Service de la Carte Géologique Detaillée de la France, p. 1-54.

- 1952. Révision des Foraminiferes Lutétiens du Bassin de Paris,

FIGURE $8-1,2$, Neorotalia viennoti (Greig), Oligocene, Ramla, Israel. 1,876512, $\times 60$, ventral view; $2,876506, \times 120$, partial, oblique ventra view of specimen with last chamber dissected. 3-7, Calcarina spengleri (Gmelin). 3, 4, 6, 7, Recent, Keij Island, Indonesia; 5, Recent, Sybai, Mindoro Island, Philippines. 3, 764013, $\times 60$, ventral view; 4, 764086, $\times 60$, oblique profile view; 5, 898137, $\times 220$, young specimen; 6, partial enlargement of 3 , showing canaliculate spines with spikes; $7,764014, \times 240$, apertural view of penultimate chamber. Note multiple intercameral foramina surrounded by thick rims in 4 and 7. c, canal; co, cover of intraseptal interlocular space (enveloping system); es, enveloping canal system with exterior openings; $f$, intercameral foramen; is, intraseptal interlocular space; li, apertural lip; sf, septal flap; sk, spikes in canaliculate spines; tp, toothplate; up, umbilical plate. 
IV. Valvulinidae, Peneroplidae, Ophthalmidiidae, Lagenidae. Mémoires du Service de la Carte Géologique Detaillée de la France, p. $1-64$.

- 1970. Contribution a l'étude des foraminiferes Paleogènes du Bassin de Paris. Cahiers de Paléontologie, Paris, Editions du Centre National de la Recherche Scientifique, p. 1-326.

- 1977. Révision des foraminifêres de la collection d'Orbigny. II-Foraminiferes de l'ile de Cuba. Cahiers de Micropaléontologie, 1:1-127.

LeVy, A., R. Mathieu, A. Poignant, M. Rosset-Moulinier, ANd A. Rouvillois. 1980. Révision de quelques genres de la famille Discorbidae (Foraminiferida) fondée sur l'observation de leur architecture interne. Révue de Micropaléontologie (1979), 22:66-88.

LOEBLich, A. R., JR., AND H. TAPPAN. 1957. Morphology and taxonomy of the foraminiferal genus Pararotalia Le Calvez, 1949. Smithsonian Miscellaneous Collections, 135(2):1-24.

- AND - 1964. Sarcodina chiefly "thecamoebians" and Foraminiferida, p. C1-C900. In R. C. Moore (ed.), Treatise on Invertebrate Paleontology, Pt. C, Protista 2. Geological Society of America and University of Kansas Press, Lawrence.

- AND - 1987. Foraminiferal Genera and Their Classification. Van Nostrand Reinhold Company, New York, Vol. 1, 970 p., Vol. 2,212 p.

Möвrus, K. 1880. Foraminiferen von Mauritius, p. 65-112. In $\mathrm{K}$. Möbius, F. Richter, and E. Martens (eds), Beiträge zur Meeresfauna der Insel Mauritius und der Seychellen. Gutman, Berlin.

MülLER-MERZ, E. 1980. Strukturanalyse ausgewahlter rotaloider Foraminiferen [Structural analysis of selected rotaliid Foraminifera]. Schweizerische Paläontologische Abhandlungen, 101:5-70.

NUTTALL, W. L. F. 1928. Notes on the Tertiary foraminifera of southern Mexico. Journal of Paleontology, 2:372-376.

- 1932. Lower Oligocene foraminifera from Mexico. Journal of Paleontology, 6:32.

OrbignY, A. D'. 1826. Tableau metodique de la classe des Cephalopodes. Annales des Sciences Naturelles, 7(1):245-314.

1839. Foraminiferes, p. 1-224. In A. Bertrand (ed.), Ramon de la Sagra, Histoire Physique et Naturelle de l'Ile de Cuba. Paris.

POAG, C. W. 1966. Paynes Hammock (Lower Miocene?) foraminifera of Alabama and Mississippi. Micropaleontology, 12:393-440.

REISs, Z. 1963. Reclassification of perforate foraminifera. Bulletin of the Geological Survey of Israel, 35:1-111.

-, AND L. HotTINGER. 1984. The Gulf of Aqaba-Ecological Micropaleontology. Ecological Studies 50, Springer-Verlag, Berlin, Heidelberg, $354 \mathrm{p}$.

- AND P. MERLING. 1958. Structure of some Rotaliidea. Bulletin of the Geological Survey of Israel, 21:1-19.

SAIDOVA, K. H. 1981. O sovremennom sostoyanii sistemy nadvidovykh taksonov Kaynozoyskikh bentosnykh foraminifer [On an upto-date system of supraspecific taxonomy of Cenozoic benthonic foraminifera]. Institut Okeanologii P. P. Shirshova, Akademyia Nauk SSSR, Moscow, 73 p.

SCHWAGER, C. 1876. Saggio di una classificazione dei foraminiferi avuto riguardo alle loro famiglie naturali. Bolletino R. Comitato Geologico d'Italia, 7:475-485.

TERQUEM, $O$. 1882. Les foraminifères de l'Eocène des environs de Paris. Mémoires de la Societé Géologique de France, sér. 3, 2(3):1193.

VeERHALLen, P. J. 1986. Morphology and function of the internal structures of non-costate Bulimina. Proceedings of the Koninklijke Nederlandse Akademie van Wetenschappen, 89:367-385.

ACCEPTED 27 JUNE 1990

\section{APPENDIX}

\section{GLOSSARY OF SELECTED TERMS}

Synonyms or terms applied by some authors in a generalized manner, pertaining also to different test elements, are in brackets.

Canaliculate spine. - Spine- or club-shaped to arborescent radial structure composed of consecutive outer lamellae enclosing canals. (Compare pseudospine.)

Canal-systems. - Term collectively and broadly applied to interconnected spaces of the foraminiferal test, primarily or secondarily sepa- rated from the main chamber lumina, but with which they may communicate in the same or in successive whorls by openings other than intercameral foramina. Canal-systems contain functional microtubular ectoplasm and represent bypasses of main chamber lumina in the whorls, directly connecting ectoplasm deep inside the early parts of the test with extrathalamous rhizopodial endoplasm. The spaces forming canal-systems are delimited by different elements of the test: umbilical plate, cover-plate joined to a foramenal plate, toothplate, septal flap, folia, previous coil, as well as consecutive outer lamellae.

Cover plate. -A more or less folded, imperforate extension of the septal flap into the preceding chamber through the intercameral foramen, cutting off, in the preceding chamber, the main chamber lumen from a foliar chamberlet. Usually attached to a preceding foramenal plate. It is a secondary feature, never present in the ultimate chamber and thus not homologous with a primary foramenal plate or umbilical plate. [Umbilical cover plate; retroparies, pars auct.]

Enveloping canals. - More or less tubular spaces parallel with the test surface formed within lateral chamber walls and communicating with intraseptal interlocular spaces. The enveloping canals are produced by (nonadhering) imperforate portions of outer lamellae, also covering partly the intraseptal spaces and folded into these spaces, leaving on both sides of this "flying cover" alternating rows of openings for ectoplasmic flow over grooves in the perforate wall, situated between imperforate inflational ridges. [Intramural cavities auct.]

Folium. - In spiral lamellar foraminifera the mostly triangular in outline and often texturally differentiated (porosity) axial-umbilical portion of the lateral chamber wall. The border between main lateral chamber wall and folium may be indicated by a short posterior indentation or "notch" or by an umbilical plate-suture. An opening (foliar aperture) is always present between the anterior margin of a folium and the adjacent previous coil. In addition, umbilical and/or posterior openings may be present, depending upon whether the folia are free or attached by their tips or along their posterior margin. In some genera folia may extend onto the preceding chamber and be attached to it, covering partly intraseptal interlocular spaces, wherever present. A folium is composed of the same layers as those forming the main chamber wall. [Lip; tenon; umbilical flap; astral lobe, pars auct.]

Foramenal plate. - Basically a primary infold in the direction of growth of the posterio-lateral chamber wall at a sutural notch, and attached to an intercameral foramen. A foramenal plate may be a short finger- or lobe-like closed structure, a short straight plate, a marginally open plate folded at an angle to the axis of coiling and attached to the adjacent previous coil, or tunnel-like and reaching a spiral interlocular space. A foramenal plate partly separates a main chamber lumen from a foliar chamberlet and is commonly in continuation of a septal flap. It may or may not be connected with a cover plate, which, in the preceding chamber, completely separates the main chamber lumen from a foliar chamberlet. (Compare umbilical plate; cover plate.) [Toothplate; paries proximus, pars auct.]

Main chamber lumen. - Complete or segmented chamber cavity produced by a single growth step and communicating with the preceding and succeeding main chamber lumina through (primary or secondary) intercameral foramina. In certain lamellar foraminifera separated partly or completely from a foliar or stellar chamberlet, as well as from canal systems by a foramenal plate, toothplate, umbilical plate, cover plate or sealing-plate, or by infolded lateral wall producing septula.

Plug [umbilical plug]. - Expanding pile of thickened lamellae in axial position in an umbilicus or in an umbilical bowl. May be canaliculate and/or compound.

Primary spiral-umbilical canal.-More or less tubular or flattened space located between umbilical plates and the wall of the preceding adjacent coil or between plates, folia, and preceding coil; or between toothplates and preceding coil; present in the ultimate chamber.

Pseudospine. - A conical, elongated, normal to wall-surface, solid inflational ornament feature, becoming spine-like through superposition of subsequent outer lamellae. (Compare canaliculate spine.) [Murica; spine; pars auct.]

Septal flap. - That part of the inner lamella that covers the preceding septal face. A septal flap may be adhering to the preceding septal face producing in this case a trilamellar septum in primarily bilamellar foraminifera; it may be separated in part from the preceding septal face along a deeply sunken suture, and thus covered by outer lamella, producing an intraseptal interlocular space. The latter may be partial and 
marginal only on one or both sides of the test or complete. The septal flap may extend into a umbilical plate, a foramenal plate, a bipartitor, a cover plate, or a toothplate. [Paries proximus, pars auct.]

Supplementary apperture(s). - Primarily formed openings either in apertural face ("apertural pores") or (slit-like) in sutural position, always in addition to a main cameral aperture. Sutural supplementary apertures are not converted into intercameral foramina because of their position and thus do not serve for passage of functional endoplasm between chambers. The same seems to be true of multiple supplementary apertures, which, although situated in the septum, may be absent in earlier chambers and may be plugged in part at a subsequent instar. [Secondary aperture(s), pars. auct.]

Toothplate. - A contorted plate running from an intercameral foramen to an aperture, attached to both. Folded in a single, double, or spiral fold. Folds (or tongues) with free, often serrated distal ends and distally protruding into the aperture. A toothplate separates partly or entirely the main chamber lumen from an axial space (adapertural depression) in post-embryonic stages. Interconnected toothplates produce a primary canal. In contrast to an umbilical plate, the toothplate is never associated with a foliar or stellar chamberlet and it does protrude with a free edge distally and adaxially to the aperture. [Sipho-central pillar, pars auct.]
Umbilical bowl. - A deep, wide or narrow conical space in axial position formed between inner umbilical chamber walls, wherever the latter are separated from the outer umbilical walls by a distinct edge or shoulder; may communicate with a true open umbilicus or may be closed by an umbilical plug. [Pseudoumbilicus, pars auct.]

Umbilical plate. -A more or less contorted plate-like test element, extending between distal and proximal chamber walls and joined to both, attached to the intercameral foramen and to the main aperture, but not protruding into the latter. Separates the main chamber lumen from a primary spiral umbilical canal, produced between plate and adjacent coil or by foliar chamberlets, or from stellar chamberlets. Between plate and adjacent coil or within the plate itself an opening provides connection between chamber and foliar or stellar chamberlet, wherever present. This opening may remain open in all chambers or it may be "plugged" in all but the ultimate chamber by a sealing plate. An umbilical plate may be single or composed of two symmetrical branches in some planispiral genera, thereby producing one or two spiral umbilical canals between plate and adjacent coil. [Foramenal plate; umbilical flap; murus reflectus; toothplate; paries proximus; pars auct.]

\title{
DISTRIBUTION AND POSSIBLE PALEOECOLOGICAL SIGNIFICANCE OF ANNECTINA VIRIOSA, A NEW SPECIES OF AGGLUTINATED FORAMINIFERA FROM NONMARINE SALT PONDS IN MANITOBA
}

\author{
R. TIMOTHY PATTERSON AND W. BRIAN MCKILLOP \\ Ottawa-Carleton Geoscience Center and Department of Earth Sciences, Carleton University, \\ Ottawa, Ontario K1S 5B6, Canada and \\ Manitoba Museum of Man and Nature, 190 Rupert Avenue, Winnipeg, Manitoba R3B ON2, Canada
}

\begin{abstract}
Annectina viriosa, a new species of Ammodiscidae (Foraminiferida), is described from Recent brackish ponds on a salt flat adjacent to Lake Winnipegosis, Manitoba. Colonization of the ponds was probably by avian transport. The distinct morphotype is either the result of an allopatric speciation event within the last 5,000 years or it is a previously undescribed species of shallowwater Annectina from nearby Hudson Bay. It is also possible that recovered specimens are previously unrecognized ecophenotypic variants of some known species produced by unknown hostile environmental factors within the pond ecosystem. The latter hypothesis is difficult to test without extensive biological culturing. The large number of phenotypically stable specimens living in these ponds warrants recognition of these populations as a distinct taxon.
\end{abstract}

\section{INTRODUCTION}

$\mathrm{D}^{2}$ URING A distributional analysis of nonmarine foraminifera from salt ponds of the Lake Winnipegosis region of Manitoba, a species of Annectina Suleymanov, 1963, was observed that was not referable to any previously described species (Patterson et al., in press). The foraminiferal fauna at most sampled Lake Winnipegosis localities was dominated by Jadammina macrescens with lesser numbers of Polysaccammina ipohalina. This fauna is very similar to those found in marshes that border Hudson Bay and James Bay (Patterson et al., 1990; Scott and Martini, 1982). Numerous previous reports attribute the establishment of foraminiferal faunas in the Lake Winnipegosis region to avian transport (Resig, 1974; Cann and De Deckker, 1981; Patterson, 1987; Patterson et al., 1990).

Difficult to explain, however, is the enigmatic occurrence of an Annectina sp. dominated fauna in brackish ponds just west of Lake Winnipegosis (Figures 1, 2; Patterson et al., 1990). Annectina is a comparatively rare genus-it has previously only been observed in Paleocene sediments from central Asiatic USSR and from Holocene deposits in Australia - and has never been reported from marsh environments, although the closely related genus Glomospira Rzehak, 1885, has occasionally been reported from estuarine environments (Scott et al., 1980). The tolerance of this latter genus to low-salinity estuarine environments may explain the tolerance of Annectina specimens for the brackish water (17.00-20.72\%) characterizing the ponds at the Lake Winnipegosis locality.

\section{METHODS AND MATERIALS}

Foraminifera were examined from a brackish pond on a salt flat $4 \mathrm{~km}$ north of the intersection of Manitoba Provincial Highways No. 20 and No. 271 (Figure 1). This locality consists of a 